\title{
Arqueologia Visual: o Uso das Imagens Fotográficas na Produção do Conhecimento Arqueológico e Historiografia da Arqueologia ${ }^{1}$
}

\author{
Sergio F. S. Monteiro da Silva* \\ Demétrio Mützenberg** \\ Daniela Cisneiros***
}

\begin{abstract}
SILVA, S.F.S.M.; MÜTZENBERG, D.; CISNEIROS, D. Arqueologia Visual: o Uso das Imagens Fotográficas na Produção do Conhecimento Arqueológico e Historiografia da Arqueologia. R. Museu Arq. Etn., São Paulo, 22: 137-156, 2012.
\end{abstract}

Resumo: Este artigo apresenta algumas perspectivas para o estudo de dados visuais produzidos por arqueólogos durante suas pesquisas. $\mathrm{O}$ uso consciente das imagens fotográficas como variações de um sistema de registro arqueológico mais amplo, incluindo a sua produção sistemática, disseminação e contexto na produção do conhecimento científico são revistas neste estudo preliminar. Desde as primeiras fotografias arqueológicas produzidas no século XIX, em atlas, catálogos e manuais, e até recentemente, com o acelerado desenvolvimento das tecnologias digitais de captação e produção de imagens visuais ao potencial analítico e interpretativo de antigos photoworks, este trabalho contribui para a compreensão sobre o uso científico das fotografias de campo e laboratório e o seu vínculo com a produção da historiografia arqueológica e seu aporte para o desenvolvimento de uma Arqueologia Visual.

Palavras-Chaves: Arqueologia visual, Sistema de registro arqueológico, Metodologia arqueológica, Fotografia, Historiografia da Arqueologia

\section{Introdução: a fotografia como documento na pesquisa arqueológica}

A fotografia é a técnica de criar documentos imagéticos bidimensionais através do registro passivo da luz e outras radiações eletromag-

$\left({ }^{*}\right)$ Mestre e Doutor em Arqueologia pelo MAE-USP; Professor de Arqueologia do Departamento de Arqueologia, Centro de Filosofia e Ciências Humanas, Universidade Federal de Pernambuco $\left.{ }^{(* *}\right)$ Mestre e Doutor em Arqueologia pela UFPE; Professor de Arqueologia do Departamento de Arqueologia, Centro de Filosofia e Ciências Humanas, Universidade Federal de Pernambuco. néticas refletidas, seja por meios químicos ou eletrônicos. Tal técnica permite uma documentação precisa do objeto, além de apresentar pela sua própria natureza menos filtros cognitivos do autor durante a criação do documento do que um registro desenhado. Permite, assim, a captação tanto de informações reconhecidas e

$\left.{ }^{(* * *}\right)$ Mestre e Doutor em Arqueologia pela UFPE; Professor de Arqueologia do Departamento de Arqueologia, Centro de Filosofia e Ciências Humanas, Universidade Federal de Pernambuco (1) Artigo extraído e modificado da dissertação de mestrado do autor, de 2001. 
intencionalmente registradas pelo autor quanto de outras informações cujo registro que não estava necessariamente previsto de ser registrado.

O estudo dos documentos visuais na perspectiva da epistemologia do conhecimento tem representado uma parcela da produção do conhecimento científico no âmbito da história, da antropologia, das ciências sociais, da medicina e ciências biológicas, da geografia, da psicologia e, mais recentemente, da arqueologia. No Brasil, Lemos (1992) preocupou-se com a construção de uma abordagem técnica da linguagem das imagens, intrínseca aos registros visuais na arqueologia, fazendo uso de preceitos retirados, por exemplo, de Susan Sontag (1981), entre outros pensadores importantes sobre a fotografia contemporânea. Os usos e significados das imagens fotográficas podem ser buscados, a priori, nos trabalhos de Roland Barthes (1984), Dubois (1990), Aumont (1993), Rouillé (2009), Kossoy (1989, 1999), Molyneaux (1997), Samain (2005) e Santaella (1998).

Até os anos 1990, a imagem visual enquanto objeto de estudo da arqueologia, segundo Molyneaux (1997), era mal compreendida ou até mesmo ignorada. As imagens produzidas pelas populações pretéritas e as produzidas pelo arqueólogo nos seus registros imagéticos são igualmente difíceis de análise e interpretação e o seu estudo enquanto documentos participantes do processo de produção de conhecimento científico ou a sua conscientização no interior da disciplina são ainda quase inexistentes. Nesse sentido, imagens visuais ${ }^{2}$ criadas pela Arqueologia podem ser traduzidas como representações de ideias vinculadas à reconstrução de contextos arqueológicos. É comum o uso das figuras na pesquisa acadêmica como suporte às ideias expressas no texto. A natureza silenciosa dessas imagens raramente tem sido discutida, assim como as suas mensagens, concordantes ou não àquelas contidas nos textos escritos.

A relevância da imagem visual reside não apenas como evidência da prática de escavação

(2) Termo utilizado em Dubois (1990), Aumont (1993), Edwards (1996), Molyneaux (1997) e Santaella \& Nöth (1998). em contextos arqueológicos, mas também como transmissora de informações arqueológicas e do olhar de cada arqueólogo sobre o seu objeto de estudo. Devemos considerar as intenções e escolhas dos produtores dessas imagens como parte das opções técnicas, metodológicas e teóricas do pesquisador e seu redimensionamento. A fotografia ainda é utilizada, geralmente, como apenas mais uma ferramenta ancilar no arsenal do pesquisador de campo. Enquanto categoria documental instável, detentora de intensa manipulação, a fotografia arqueológica se mostra como recurso para auxiliar na formulação de problemas e no enunciado de hipóteses a partir de um photowork ${ }^{3}$. Nesse caso, as séries de fotografias arqueológicas constituem um aspecto de como o arqueólogo pode evidenciar os remanescentes do passado e trabalhar sobre eles, fornecendo mais informações do que podemos perceber quando são realçadas e ampliadas. Essas imagens estão vinculadas à ideia da fotografia como um documento na produção do saber na arqueologia e, mais especificamente, como recursos de informações segundo Erskine (1965).

A fotografia como documento ou fotografia-documento, na perspectiva de Rouillé (2009), vislumbra o fotográfico como sendo essencialmente operatório. $\mathrm{O}$ ato fotográfico na arte e nas ciências, incluindo a arqueologia, estaria vinculado aos seguintes objetivos: a) arquivar, quando ocorre a união entre fotografia-álbum ou fotografia-arquivo; b) ordenar, quando a fotografia-arquivo classifica, ordena o que a fotografia fragmentou; c) fragmentar, pois o fotógrafo desarticula a continuidade do real visível para produzir imagens; d) unificar, quando a partir da efusiva multiplicidade de tomadas parciais a fotografia-documento é tratada pelas tomadas panorâmicas, álbuns e arquivos; e) modernizar os saberes, a partir da redução da subjetividade dos documentos produzidos pelo saber científico, com o registro sem interpretações, autenticação ou substituição do objeto, dos mundos visível e

(3) Termo entendido aqui como um conjunto de fotografias vinculado a uma pesquisa científica. A utilização desta designação pode ser encontrada em Shanks (1992, 1997). 
invisível; f) ilustrar, uma orientação do dispositivo fotográfico ocorrida desde o final do século XIX para integrar-se a um protocolo experimental específico de uma ciência; g) informar, a função mais importante da fotografia-documento e se dá com a sua inserção na imprensa, com a publicações impressas ou digitais.

Esses objetivos da fotografia-documento, conforme Rouillé (2009), favoreceram, durante todo o séc. XX, a criação de visibilidades inovadoras para a modernização científica. $\mathrm{O}$ dispositivo fotográfico contribui no processo de produção, arquivo ou difusão do conhecimento das ciências e, naturalmente, da arqueologia, pelo registro, representação, por atestar, facilitar demonstrações, documentar experimentos, acompanhar o ensino e o trabalho de pesquisadores.

Então, na arqueologia, os documentos fotográficos são possuidores de dois importantes papéis: o de documentar a pesquisa de campo e comunicar as atividades e resultados da pesquisa arqueológica em aulas, palestras e audiências gerais (Struever, 1995). Consequentemente se constituem tais registros em formas de exposição dos resultados e dos métodos de evidenciação e mesmo da abordagem utilizada pelo arqueólogo. Para Collier (1995), arqueólogos, em suas necessidades de definir detalhes e precisar associações de materiais, genuinamente estabeleceram três modos de utilização científica das fotografias: para mensurar, para contar e para comparar. Esses objetivos complementam aqueles sugeridos por Rouillé (2009) para o ato fotográfico na arqueologia.

A fotografia arqueológica se dá mediante diversas técnicas, registrando um processo temporário e irreversivel, claramente exemplificado nas atividades de escavação (Cf. Figura 1). Esses registros visuais representam imagens que podem ser legitimadas no domínio científico e disciplinar. Um conjunto de fotografias para poder ter forma coerente, deve possuir uma linguagem e estar vinculado a um processo narrativo através de um texto. Cada fotografia é dependente da relação com as demais e/ou com textos e é "arqueológica" quando o arqueólogo pode extrair informações visuais úteis e significativas nas várias etapas de pesquisa.

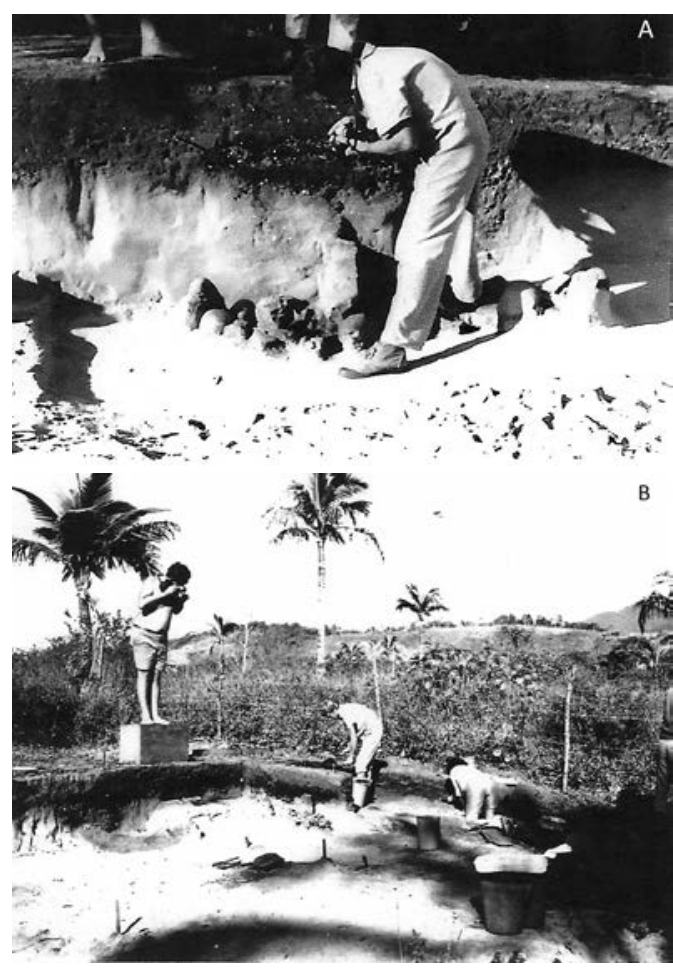

Fig. 1: Atividades de registro fotográfico dos enterramentos humanos no sítio Tenório em 1970. a) Caio Del Rio Garcia realiza fotografias verticais do enterramento $\mathrm{XX}$; b) Walter Guerreiro realiza fotografias oblíquas de um conjunto de quadras e do enterramento XXVI. (Fonte: MAE - USP, 2001).

O problema do uso das imagens visuais da arqueologia $^{4}$, não daquelas criadas pelas populações pretéritas, mas aquelas produzidas pelos próprios arqueólogos e suas equipes, durante trabalhos de campo como dados de registro sobre os vestígios de cultura material e de seus criadores está no seu modo de utilização, de conscientização em relação à modalidade teórico-metodológica aplicada durante a escavação. O reconhecimento visual de dados e eventos

(4) Ver as considerações, embora restritas às fotografias aéreas e seu tratamento digital de Irwin Scollar e o artigo de Erik Nylén sobre o uso de fotografias de Raios-X e fotogrametria em vestígios enterrados e ainda as definições de Michael B. Schiffer, Sullivan e Klinger de visibilidade, acessibilidade e reconhecimento de sítios e vestígios em arqueologia, além de sua bibliografia a respeito: World Archaeology (Field techniques and Research Design), Oxford University Press, v. 10, p. 1-28, 71-87, 88-93, 1978. 
Arqueologia Visual: o Uso das Imagens Fotográficas na Produção do Conhecimento Arqueológico e Historiografia da Arqueologia

R. Museu Arq. Etn., São Paulo, n. 22: 137-156., 2012.

\begin{tabular}{|l|l|}
\hline \multicolumn{2}{|c|}{ Observação humana } \\
\hline Por meio da máquina fotográfica & Sem o uso da máquina fotográfica (normal) \\
\hline $\begin{array}{l}\text { Quando a claridade e abrangência do foco é ampla, com pro- } \\
\text { fundidade limitada de campo e proporcional ao ângulo da } \\
\text { lente, abertura pequena ou grande profundidade de campo }\end{array}$ & Amplo alcance do foco \\
\hline $\begin{array}{l}\text { A perspectiva varia com o ângulo da lente, dependendo do } \\
\text { senso de perspectiva do fotógrafo }\end{array}$ & Perspectiva variável \\
\hline Profundidade vista é aparente & A profundidade nunca é totalmente definida \\
\hline $\begin{array}{l}\text { O limite da imagem se dá pelas barreiras físicas de uma } \\
\text { moldura }\end{array}$ & Seu limite físico é ilimitado ou muito extenso \\
\hline $\begin{array}{l}\text { As linhas paralelas da luz convergem para as bordas laterais } \\
\text { através de uma superfície sensível, contendo margens e } \\
\text { declives }\end{array}$ & $\begin{array}{l}\text { As linhas paralelas da luz se estendem paralela- } \\
\text { mente e em profundidade }\end{array}$ \\
\hline $\begin{array}{l}\text { Contém informações sobre o mundo dos signos ou objetos } \\
\text { reconhecíveis }\end{array}$ & $\begin{array}{l}\text { Relaciona-se a um mundo de objetos, de } \\
\text { signos, sinais e sentidos }\end{array}$ \\
\hline
\end{tabular}

Quadro 1: Atributos da observação humana, segundo Nichols (1981)

ocorridos durante uma escavação arqueológica depende das sistemáticas de análise e interpretação das imagens adotadas pelo arqueólogo. As diferenças ou os filtros existentes entre a visão fotográfica e a visão normal evidenciam as diferenças entre o objeto a ser fotografado e a imagem fotográfica do mesmo. Nichols (1981) estabeleceu diferenças entre a observação fotográfica e a percepção visual normal. Os atributos específicos da observação fotográfica e da humana estão discriminados no Quadro 1.

Michael Shanks (1997), com o objetivo de contribuir para o surgimento de novas metodologias arqueológicas ${ }^{5}$, entende as fotografias como apoios técnicos, servindo para registrar ou identificar eventos e objetos, fornecer paisagens de fundo e também cenários ilustrativos para

(5) As novas metodologias arqueológicas propostas por Shanks referem-se àquelas chamadas pós-processuais e que seriam agora melhor conhecidas como interpretativas, preocupadas com a interpretação e compreensão (percepção, entendimento, inteligibilidade) dos materiais do passado. Sustenta que a habilidade de provar, citar e gradativamente manipular o mundo visual através da constante implementação e desenvolvimento das tecnologias visuais, oferece grande alcance para apresentarmos passados com texturas mais ricas. museus. Elas são tratadas como janelas abertas ao passado. Para Shanks, a fotografia arqueológica pode ser abordada do ponto de vista de um estudo da cultura, sendo assim objeto para uma sociologia do conhecimento: a fotografia é um objeto de cultura material relacionado, por exemplo, à história das ciências e da observação científica; serve como documento historiográfico da arqueologia.

Segundo Shanks (1997), as fotografias são, muitas vezes, usadas para registrar, documentar e ilustrar o que foi escavado e o que estava sendo discutido em um texto. Mediante boas instruções em manuais de fotografia arqueológica, é possivel obter registros precisos e completos sobre os vestígios escavados. A fotografia é um meio para o registro objetivo, é demonstrativa, pronominal, re(a) presentativa do objeto fotografado. As fotografias produzidas durante os trabalhos de campo na aquisição e registro de dados, prestam-se a demonstração e suplementação das anotações dos cadernos de campo. Registram importantes associações espaciais dos vestígios em contexto arqueológico e servem para a verificação das técnicas de escavação. São, aqui, uma questão técnica, para servir como meio e não fins: a fotografia arqueológica é um meio para o registro objetivo. 
Assim, na produção arqueológica como produção cultural, o photowork revela um aspecto sobre como o pesquisador levanta os remanescentes do passado no presente e trabalha sobre eles:

In the texture of their detail photographs provide a partially involuntary record. There is always in every photograph some processed experience. That the materiality of the world is ineffable is presented. Finally, temporality, often a melancholy of the past in the present, is invoked throughout photowork (SHANKS, 1997, p.100)

Segundo Shanks (1997) existem quatro áreas de interesse dentro de uma sociologia do conhecimento arqueológico para as quais poderiam estar voltadas potencialmente as séries de fotografias arqueológicas, que: a) relacionam-se com o conceito de atualidade na medida em que a temporalidade do photowork é análoga a temporalidade do discurso arqueológico e seus objetos; b) prestam-se a uma etnografia da disciplina arqueológica na medida em que constituem uma parcela explanatória e documental dos projetos arqueológicos; c) expressam o inefável e o heterogêneo na arqueologia, na medida em que enriquecem com detalhes uma maior compreensão das realidades sociais passadas, suspendendo ou redimensionando as categorizações e esquemas convencionais no discurso arqueológico; d) servem, no trabalho interpretativo, como citações por meio da edição e da montagem nos textos, convidando a experimentar como as associações de imagens remetem a atualidade do passado.

Nesse sentido, as fotografias enquanto photoworks estariam intimamente relacionadas ao caráter do discurso arqueológico sobre as realidades sociais passadas, prestando-se em primeiro lugar, ao estudo do conhecimento arqueológico - uma historiografia arqueológica ${ }^{6}$.

A fotografia, quando é usada para análise do dado de campo, aplica-se nos estudos indiretos do fenômeno observável do contexto arqueológico. Uma vez terminada a escavação, qualquer recorrência a esses dados implica na dependência

(6) Termo entendido aqui como uma reflexão acerca da evolução da arqueologia como disciplina científica. do arqueólogo em relação aos registros fotográficos, que fornecem imagens estáticas da pesquisa de campo para análise e interpretação.

Fotografias usadas para revisão e análises de coleções arqueológicas são viáveis a partir da inacessibilidade das características desses materiais e seu contexto arqueológico, servindo como guias de estudo sob a forma de catálogos sistemáticos de coleções arqueológicas como o Corpus Vasorum Antiquorum ${ }^{7}$. Sob uma perspectiva ampla, todos os estágios da análise e interpretação arqueológica são auxiliados pelo uso das fotografias e demais categorias de imagens produzidas em campo. Durante uma escavação, servem para registrar as características de uma superfície plana, um perfil, um tipo ou conjunto de artefatos, sepultamentos humanos, entre outros. Devem ser anotadas as informações sobre qual área do sítio está sendo representada, a quadra, setor, quadrícula, a direção na qual foi obtida a fotografia, a escala, o nome do fotógrafo, o número do filme e das poses. Essas anotações em ficha ou caderno específicos para os registros fotográficos são constantemente utilizadas enquanto informações necessárias a interpretação das imagens produzidas.

\section{História da fotografia-documento na arqueologia}

As primeiras fotografias de arqueologia surgiriam na primeira metade do século XIX, em 1852, quando o Trustees of the British Museum, consultando Fox Talbot ${ }^{8}$ e sob a coordenação de

(7) Corpus Vasorum Antiqurorum (Corpos de Vasos Antigos) é um antigo projeto de pesquisa da Union Académique Internationale, que consiste em uma série de catálogos científicos de antigos vasilhames cerâmicos, sobretudo gregos. Seu primeiro fascículo foi publicado em 1922.

(8) William Henry Fox Talbot (1800-1877) em 1934 começou a fazer experiências fotográficas, e entre 1835 e 1840 fez e apresentou a primeira forma de negativo utilizada em fotografia, o calótipo ou talbótipo. Trata-se de um negativo obtido em papel comum impregnado de iodeto de potássio e sensibilizado por uma solução de nitrato de prata e ácido gálico. Depois de exposta na câmara fotográfica, a imagem latente era revelada pelo mesmo banho usado como sensibilizador e fixada por hipossulfito de sódio. Normalmente, depois de exposta, era encerada, a fim de lhe aumentar a translucidez. Talbot patenteou esse processo em 1841, na Inglaterra, publicando entre 1844 e 1846 "The Pencil of Nature" (EHRLICH, 1986, p.44-257) 
Brooke, o superintendente do Departamento Fotográfico do Observatório Real e Wheatstone, físico e inventor do eletrotelégrafo, providenciaram o registro fotográfico das tabletes cuneiformes do acervo do museu. No mesmo Trustees, em 1853, Roger Fenton providenciou um laboratório para fotografar pelo processo da calotipia grande número de artefatos arqueológicos, tabletes e inscrições que haviam sido trazidos após as escavações de Sir Henry Layard em Nínive (Nimrud).

Outras contribuições, segundo Philibert, revisitado por Chéne e Rèveillac (1975), advém das séries de fotografias de monumentos no Egito, Núbia, Palestina e Síria produzidas por M du Camp durante seus trabalhos com Flaubert de 1849 a 1851. Em 1951, L.D. Blanquart-Evrard empreendeu uma impressão fotográfica em Lille, usando uma modificação do processo de calotipia de Fox Talbot, produziu um catálogo com 125 fotografias de $\mathrm{M}$ du Champ, tornando acessíveis as imagens dos monumentos orientais aos estudantes e ao grande público. Provavelmente a primeira expedição arqueológica a fazer uso de fotografia em campo foi a de R. Lepsius ao Egito entre 1842 e 1845 . Entretanto os trabalhos fotográficos em daguerreotipia (EHRLICH, $1986)^{9}$ e calotipia mais significativos foram produzidos por M Tranchard durante as escavações de V. Place na Assíria de 1852 a 1855 (PILLET, 1962) e publicados sob a forma de gravuras em Place (1867).

$\mathrm{O}$ uso da fotografia de campo integrou as pesquisas de A Salzann nos sítios bíblicos da Palestina em 1854 e as escavações de Jerusalém empreendidas pelo capitão Wilson em 1860. As escavações em Tebas, no Egito, procedidas por J. B. Greene em 1855 resultaram em fotografias pelo processo da calotipia. Na segunda metade

(9) Um dos primeiros processos de obtenção de imagens fotográficas inventado pelo francês Louis Jacques Daguerre (1787-1851) que produz uma imagem positiva direta em chapa de cobre coberta de uma fina camada de prata cuidadosamente polida e sensibilizada com vapores de iodo. A imagem latente é revelada com vapores de mercúrio e a imagem é apresentada em um caixilho hermeticamente fechado. Esse processo foi apresentado publicamente por Daguerre em 1839 e esteve em uso até cerca de 1860 do séc. XIX, Newton (1862) publicou os resultados das escavações na Grécia e Turquia com litogravuras baseadas nas fotografias obtidas nos sítios escavados. Mas os primeiros resultados de pesquisas arqueológicas que fizeram uso das fotografias impressas (não como litografias ou gravuras derivadas de fotografias) foram publicados em Conze et al. (1880) sobre seus estudos na Samotrácia. Em 1865 eram produzidas as primeiras imagens com uso de flash a base de magnésio do interior das câmaras da Grande Pirâmide por C P Smith (FEYLER, 1987).

Nos Estados Unidos, W. H. Jackson, fotógrafo da American West, fez os primeiros registros de Mesa Verde e outros sítios pueblo dos estados do sudoeste em 1870. Em 1880, A P Maudslay, E H Thompson e T Maler fizeram uma série de registros fotográficos de monumentos arqueológicos do México, contribuindo com o grande arquivo do Peabody Museum. A fotografia arqueológica de campo foi intensamente utilizada por F. W. Putnam durante suas escavações em Ohio em 1890, servindo como meio para ilustrar os monumentos arqueológicos. Os trabalhos de Muñiz e Mc Gee (1897) resultaram na divulgação de 40 fotografias da coleção de crânios peruanos trepanados do Smithsonian Institution. Mais tarde, com os estudos de Vignati (1930) foram publicadas 73 fotografias dos crânios troféus de Humahuaca, Jujuy. Photoworks de remanescentes arqueológicos, incluindo sepultamentos humanos, já estavam sendo produzidos intensamente nos primeiros anos do século XX, como o grande arquivo de imagens produzidas durante as escavações no cemitério pré-dinástico egípcio de Naga Ed Er, por Lythgoe (1965) e com os trabalhos que se utilizaram das ilustrações fotográficas - fotografia-documento - como o de Hrdlička (1910). Na documentação de registros rupestres, a fotografia foi utilizada desde o século XIX, tendo como pioneiros, na sua utilização, Von Bonde na África em 1885 e Holmes nos Estados Unidos em 1876 (Bahn, 2010) e Chirón na França em 1878 (Martínez e Loizeau, 2006).

Durante o fim do século XIX e primeira metade do XX, a fotografia veio sendo utilizada como um dos recursos técnicos da escavação e do registro de artefatos e esqueletos humanos. 

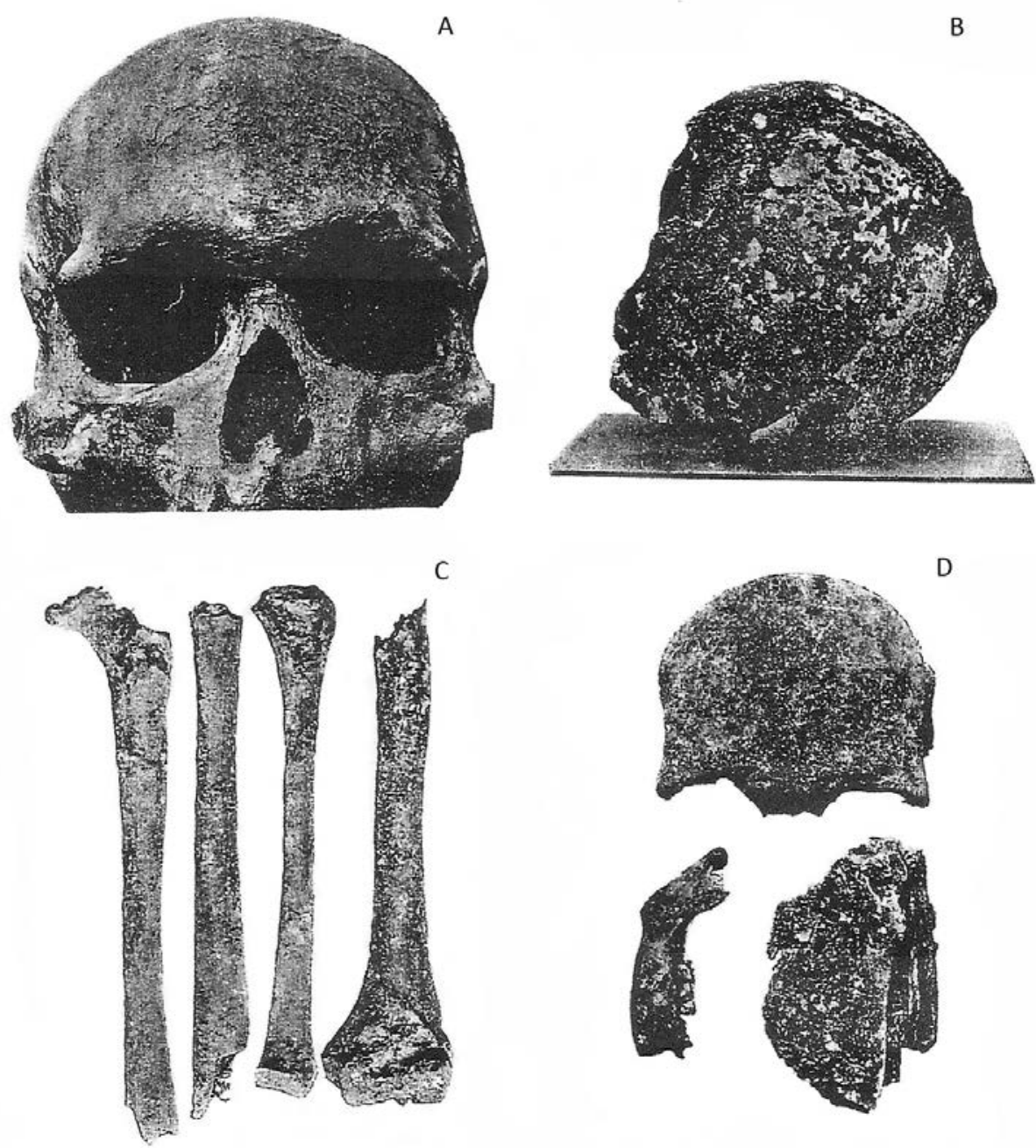

Fig. 2: Documentos fotográficos de ossos humanos coletados e registrados por Loëfgren em 1893: a) crânio nº 1 do Sambaqui Passa-Mirim; b) crânio n ${ }^{2}$ 2, Passa-Mirim; c) ossos longos, sambaqui de Guayuba; d) frontal, fragmentos de mandíbula e ossos longos concrecionados, sambaqui Boguassu. (Fonte: LÖFGREN, 1893)

Em 1880 já eram questionadas as potencialidades da fotografia aérea10 com o uso de balões para o registro de sítios no Oriente Médio, realizadas somente com o advento da Primeira Guerra Mundial. A ideia de que as fotografias de campo podem revelar vários detalhes da escavação, bem como seu processo, com precisão e obedecendo

(10) A aerofotografia é tomada de vistas feitas de avião, balão, entre outros. Utilizada como levantamento fotográfico e geodésico da superfície terrestre denomina-se aerofotogrametria. A utilização da fotografia aérea para a topografia - aerotopografia ou topografia fotogramétrica - destina-se à confecção de mapas. os princípios básicos referentes à formação da imagem, perspectiva e distorção, foco e exposição assim como as lentes e a iluminação ideais para cada caso, foi defendida insistentemente pelo fotógrafo M B Cookson (1954). Essa ideia constitui o cerne da prática da fotografia arqueológica contemporânea, profundamente remodelada com o advento da fotografia digital e de recursos diferenciados de captação de imagens tridimensionais digitalizadas ou escaneadas.

No Brasil as primeiras fotografias arqueológicas de campo e de materiais antropológicos foram publicadas em Lacerda Filho e Rodrigues 
Arqueologia Visual: o Uso das Imagens Fotográficas na Produção do Conhecimento Arqueológico e Historiografia da Arqueologia

R. Museu Arq. Etn., São Paulo, n. 22: 137-156., 2012.

Peixoto (1876), Löfgren (1893) e Krone (1914), estudiosos vinculados ao Museu Nacional do Rio de Janeiro e à Comissão Geográfica e Geológica do Estado de São Paulo (Cf. Figuras 2 e 3). Foi o próprio Löefgren que produziu as 17 fotografias que ilustram seu trabalho de 1893 sobre os sambaquis de São Paulo, assim como Krone foi o fotógrafo das escavações que realizou nos sambaquis do rio Ribeira entre fins do século XIX e a primeira década do XX.

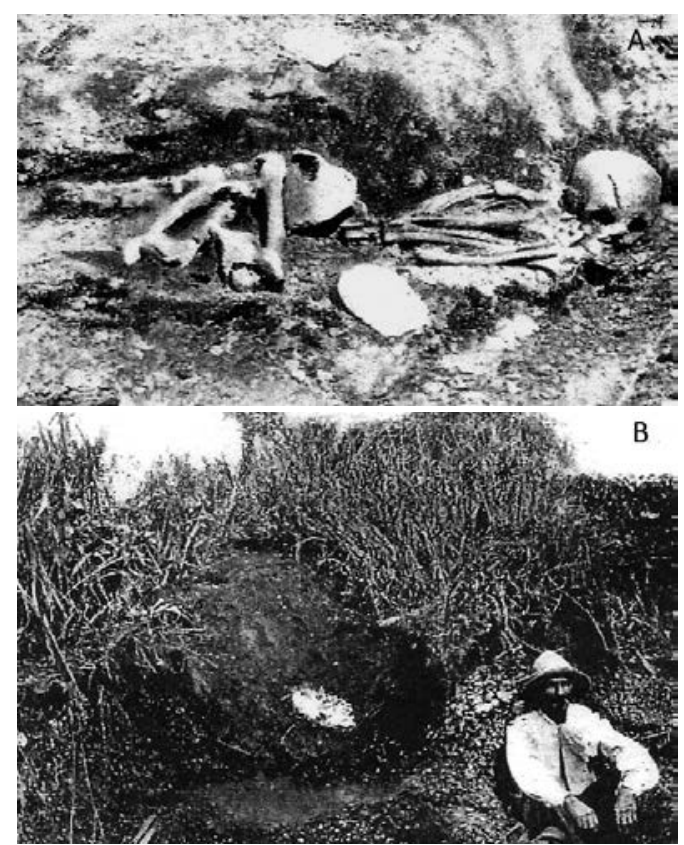

Fig. 3: Impressão de documento fotográfico publicado em Krone, 1914. a) esqueleto $n^{\circ} 8$ do sambaqui do Roccio, Iguape; b) esqueleto do sambaqui de Vila Nova, Mar Pequeno Iguape, coberto com osso chato de baleia. (Fonte: KRONE, 1914).

Usos da fotografia na arqueologia: os olhares positivos dos manuais

O emprego da técnica fotográfica - tradicional, digital, instantânea, entre outros -, quer pelo arqueólogo ou fotógrafo técnico especializado, busca uma variedade de propósitos. As imagens produzidas constituem meios ou fins de etapas dentro da pesquisa, durante uma escavação, análises laboratoriais e musealização do conhecimento arqueológico, cumprindo a missão de socialização de um saber científico. Deparamo-nos com extensões da tecnologia digital na prática fotográfica que demandam um alfabetismo constante do arqueólogo em relação ao quê, porque e como fotografar, ou mesmo em relação ao planejamento e organização da própria pesquisa. Surge a questão dos múltiplos implementos tecnológicos voltados a produção de imagens (fotográficas, filmicas, eletrônicas, digitais) e suas formas de uso e interpretação na arqueologia.

Muito do trabalho fotográfico produzido durante uma escavação arqueológica está relacionado a uma série de problemas científicos, cada qual devendo ser resolvido em ordem para que seja produzido um registro compreensível. Esse registro expressa elementos inerentes à prática arqueológica, aos métodos e técnicas de escavação e aos objetivos e justificativas de uma pesquisa. Assim, um levantamento fotográfico inclui: um diário de registro fotográfico da escavação; registros detalhados de perfis estratigráficos; registro de estruturas arquitetônicas; registros de artefatos e outros vestígios in situ; um registro catalográfico de todos os objetos; vistas panorâmicas do sítio e diapositivos para ilustrar palestras e para divulgação acadêmica e ao grande público: uma história em imagens do sítio, das atividades diárias e das descobertas.

A identificação do potencial de análise e interpretação de um photowork para relatar os diferentes sentidos, propósitos, interesses e funções do discurso arqueológico passaria a ser considerada como uma contribuição metodológica, vinculada à interpretação e a compreensão da cultura material do passado ou em determinadas instâncias da teoria arqueológica explanatória, formativa, de recuperação, formal e inferencial. Essa identificação das fotografias como documentos visuais na pesquisa arqueológica depende do sistema de registro adotado e sua relação com o discurso arqueológico, subordinando-se aos propósitos, interesses e funções desse mesmo discurso. Essas imagens constituem informação, prova, registro, ilustração, testemunho visual de um fato arqueológico.

Os registros fotográficos são fixos, mas com diversidades de interpretações tantos quantos forem seus interpretantes. A análise e a interpretação desses registros partem do pressuposto 
do entendimento dos significados do caráter múltiplo objetividade-prova e representatividade-subjetividade que contém. Assim o universo real da prática arqueológica de campo, impregnado das diretrizes teóricas, passa a ser objetivamente representado pelo olhar do fotografo através da câmara e seu resultado mediante a ampliação das fotos em suportes sensíveis ou o seu processamento digital e reconhecidos pelo olhar dos intérpretes. Utilizar imagens como fontes fotográficas significa considerar o seu caráter de registro, relacionado à maneira como o arqueólogo documenta o contexto arqueológico. A fotografia aqui está sendo considerada como artefato e registro visual de uma forma iconográfica empregada no trabalho arqueológico. Para Boris Kossoy,

\section{[...] as imagens que contenham um} reconhecido valor documentário são importantes para os estudos específicos nas áreas da arquitetura, antropologia, etnologia, arqueologia, história social e demais ramos do saber, pois representam um meio de reconhecimento da cena passada e, portanto, uma possibilidade de resgate da memória visual do homem e do seu entorno sociocultural. (KOSSOY, 1989, p. 35-36).

Nessa perspectiva, uma teoria não só confere qualidade ao dado, senão também permite reconhecer os vazios de informações existentes e as falhas e acertos presentes nas interpretações realizadas dentro de marcos teóricos diferentes. Serve para ordenar, classificar e comparar os dados arqueológicos visando dar inteligibilidade aos vestígios arqueológicos, objeto da arqueologia. Entretanto, conforme a abordagem teórica e metodológica despendida num estudo arqueológico, as imagens podem se tornar não significantes no projeto científico em questão, mas significantes para outros estudos de ciências correlatas, como a Antropologia Visual e a História.

A Arqueologia, tanto quanto a Antropologia - a Antropologia Visual - e a Etnografia utilizam-se dessas duas categorias perceptivas para suas produções de conhecimento. Observar em arqueologia implica, segundo Arenas (1986), em conhecer previamente o que se vai observar: é decidir, determinar qualitativamente o sujeito da observação. Este primeiro nível metodológico permite o acúmulo de observações qualitativas e sua determinação quantitativa (ARENAS, 1986). Nesse sentido, as observações em Arqueologia devem estar imbuídas do conhecimento de que todo dado arqueológico se manifestou em um espaço e tempo dados. Estas duas variáveis permitem estabelecer, para efeitos da observação, o conhecimento do movimento e as interações de causalidade. Assim, observar dados arqueológicos pressupõe registrar as manifestações espontâneas dos fenômenos que, em suas relações ou associações contextuais, manifestam uma temporalidade, uma espacialidade e uma dinâmica próprias:

Ao obter e registrar seus dados em campo, o arqueólogo destrói parte das evidências, não obstante a recrie em suas notas; entretanto esta recriação nunca corresponderá exatamente a realidade da qual foi obtida. Ao não poder reproduzir fielmente a realidade observada, o arqueólogo produz alterações nos dados, referentes do processo que estuda (ARENAS, 1986, p.17)

As perturbações ocasionadas durante a obtenção dos dados arqueológicos devem ser minimizadas por meio das técnicas e instrumentos de escavação adequados, registrando e quantificando as modificações ocasionadas pela escavação que serão posteriormente consideradas no momento da análise dos resultados. Como princípios que norteiam a acumulação do dado empírico em arqueologia (LUMBRERAS, 1982). temos os meios de acesso ao objeto de estudo, constituídos pelos equipamentos de medição e os instrumentos para a escavação; um sistema de registro e a descrição detalhada de todos os aspectos do processo de acumulação de dados.

As imagens feitas ou produzidas no passado e as imagens produzidas para reapresentar o passado são igualmente difíceis de analisar. Para Molyneaux (1997), é comum o uso de figuras na pesquisa acadêmica como auxílio as ideias expressas de outras maneiras. Imagens podem ser criadas com qualidades estéticas, mas tendem a ser re(a)presentações de ideias, ou ilustrações de eventos. Aquilo que cada figura comunica aos re- 
Arqueologia Visual: o Uso das Imagens Fotográficas na Produção do Conhecimento Arqueológico e Historiografia da Arqueologia

R. Museu Arq. Etn., São Paulo, n. 22: 137-156., 2012.

ceptores, a natureza de suas mensagens silenciosas, raramente é discutido. As imagens possuiriam um poder e influência como depoimentos diretos sobre ideias sociais e relações, mensagens visuais que podem ser vigorosas e distintas daquelas contidas nos textos. No território da produção de conhecimento arqueológico inúmeros manuais destacaram-se, entre os anos $1950 \mathrm{e}$ 1990, no processo de direcionar a fotografia como auxílio dessa produção em campo ou no laboratório, como os trabalhos específicos sobre a fotografia de arqueologia de Cookson (1954), Conlon (1971), Harp (1975) e Dorrell (1995). Manuais, abrangendo técnicas arqueológicas em geral incluem seções sobre fotografia, como os trabalhos de Heizer e Graham (1967), Barker (1977) e Joukowsky (1986). A fotografia representa na arqueologia a implementação da prática da conservação, do registro objetivo de campo e de laboratório e da documentação com fins de catalogação, divulgação e propaganda das pesquisas arqueológicas. Mesmo o posicionamento da câmera e a normatização do olhar para o registro fotográfico objetivo, a fotografia vertical e oblíqua, é uma preocupação recorrente em Barker (1977), reafirmando as prerrogativas de Cookson (1954) e Mathews (1968), retomadas mais tarde por Pallestrini e Perasso (1984). Os primeiros questionamentos e problematizações sobre a produção e o uso das fotografias pela arqueologia advém dos estudos de Harp (1975) e Shanks (1997).

A identificação de um potencial do trabalho fotográfico de arqueologia serve ao relato dos propósitos, interesses e funções dos discursos arqueológicos. Esse procedimento contribuiria as novas metodologias arqueológicas, preocupadas com a interpretação e compreensão dos remanescentes do passado. Quando os catálogos de materiais arqueológicos contém muitas informações descritivas, com ilustrações complementares de croquis, plantas e fotografias de tipos de vestígios para comparações, constituem instrumentos de pesquisa. Assim:

The visual is not merely illustrative. [...] Photographs and drawings of artifacts in a catalogue are there to provide information which cannot be encapsulated in verbal description. But the imperative remains, in spite of any emphasis on photowork and discourses of archaeology, to record and make inventories. Her too new storage technologies, recording and retrieval systems are already having effect. Multimedia databases are now cheap and efficient. Videos, still images, text, sound, and graphics can all be combined within the same coordinated recording system. This has been much taken up in archaeology already as an extension of conventional methods (SHANKS, 1997, p. 92-99, 100-101)

Durante o tempo em que o arqueólogo trabalha no sítio, vai naturalmente estudando fenômenos diretamente observáveis. Quando um contexto é totalmente escavado deixa de existir no sítio e passa a estar representado em sistemas de registro, bancos de dados de imagens e textos, para quaisquer revisões e análises posteriores. Um contexto de escavação deverá sempre vir a ser uma representação arqueológica, suficiente ou insuficiente, desse mesmo contexto. Nessa perspectiva, Harp (1975) ressaltou importantes observações sobre o uso das fotografias para a análise de coleções:

In winder perspective, all stages of archaeological analysis and interpretation can benefit from the use of documentary specimen photography. If one needs to examine comparative materials that happen to be stored in some institution half-way around the world, good photography will usually be an adequate substitute. Even in one's own laboratory it will sometimes be easier to work analytically from a bath of photographs than it is to manipulate a collection of specimens. This consolidation and concentration of images and information often saves time for the research worker (HARP, 1975, p. 11)

Harp (1975) considerou as fotografias arqueológicas como possuidoras de quatro propósitos básicos: o da aquisição e registro de dados, análise e interpretação e para comunicações. Suas funções específicas na obtenção de dados estariam na pesquisa e descoberta, análise ambiental, fotogrametria e mapeamento. Como registro de dados funcionaria como documen- 
tário operacional, registrando os trabalhos de campo e servindo a catálogos e arquivos. Com objetivo de análise e interpretação prestar-se-ia a análise de dados de campo e de coleções e como comunicação seriam utilizadas em aulas, palestras e publicações (Quadro 2).

\section{A fotografia como auxílio na produção do conhecimento arqueológico: os photoworks e seus potenciais}

$\mathrm{O}$ interesse em explorar as possibilidades dos registros visuais produzidos em arqueologia e examinar sua integração como evidência do passado, entre outras formas tradicionais de transcrever e transmitir informações arqueológicas, deve contribuir para a compreensão arqueológica dos vestígios produzindo dados arqueológicos sob a forma de photowork, dentro de um amplo sistema de registro.

O estudo dos registros fotográficos deve estabelecer um diálogo entre os trabalhos de campo e de laboratório, propondo possibilidades de interelação dos dados observáveis (da observação visual humana) entre o vestígio, os dados escritos e os dados fotografados no contexto de campo mediante um "alfabetismo visual". A detecção do estado desse "alfabetismo" através da análise e interpretação dos documentos visuais pode resultar em reformulações dos métodos e técnicas de registro-documentação na disciplina arqueológica.

Determinado potencial informativo a ser identificado pela análise e interpretação dos documentos fotográficos (KOSSOY, 1989, 1999) produzidos na Arqueologia poderá ser assim esquadrinhado (Quadro 3):

Em decorrência das atividades de escavação, as possibilidades de observação sistematizada dos vestígios e estruturas arqueológicas, suas relações, sua distribuição espacial e temporal tornam-se iminentes e logo originam certas categorias de documentos visuais representados pelas imagens fotográficas, fílmicas, eletrônicas e informáticas. Entre os meios e instrumentos utilizados para gravar as impressões de determinados momentos da escavação arqueológica podem, ainda, surgir os desenhos manuais (croquis, planos e mapas), coloridos ou não, em associação com pequenos textos, constituindo uma forma de nota arqueológica.

Para Collier (1995), arqueólogos, em suas necessidades de definir detalhes e precisar associações de materiais in situ, genuinamente estabeleceram três modos de uso científico das fotografias: para mensurar, para contar e para comparar. Uma escavação arqueológica - início de um processo

\begin{tabular}{|l|l|l|l|l|}
\hline \multicolumn{5}{|c|}{ Fotografia arqueológica } \\
\hline Objetivos principais & Obtenção de dados & \multicolumn{1}{|c|}{ Registro de dados } & $\begin{array}{l}\text { Análise e inter- } \\
\text { pretação }\end{array}$ & \multicolumn{1}{c|}{ Comunicação } \\
\hline Funções específicas & $\begin{array}{l}\text { Pesquisa e descober- } \\
\text { ta, análise ambien- } \\
\text { tal, fotogrametria e } \\
\text { mapeamento }\end{array}$ & $\begin{array}{l}\text { Documentário opera- } \\
\text { cional, fotografia dos } \\
\text { trabalhos de campo, } \\
\text { catálogos e arquivos }\end{array}$ & $\begin{array}{l}\text { Análise de dados } \\
\text { de campo, análise } \\
\text { de coleções }\end{array}$ & $\begin{array}{l}\text { Comunicações } \\
\text { profissionais, } \\
\text { aulas, relações } \\
\text { públicas }\end{array}$ \\
\hline Ambientes & Ártico, temperado, desértico, tropical, marinho \\
\hline Métodos & Aéreo, superficial, subaquático \\
\hline Sistemas técnicos & Câmera, lentes, emulsões, processamento \\
\hline Escalas & Macro, micro \\
\hline Modos & Plano, estereoscópico \\
\hline Audiências & Pessoais, profissionais, para estudantes, palestra pública \\
\hline
\end{tabular}

Quadro 2: Elementos da prática fotográfica na pesquisa arqueológica, segundo Harp (1975) 


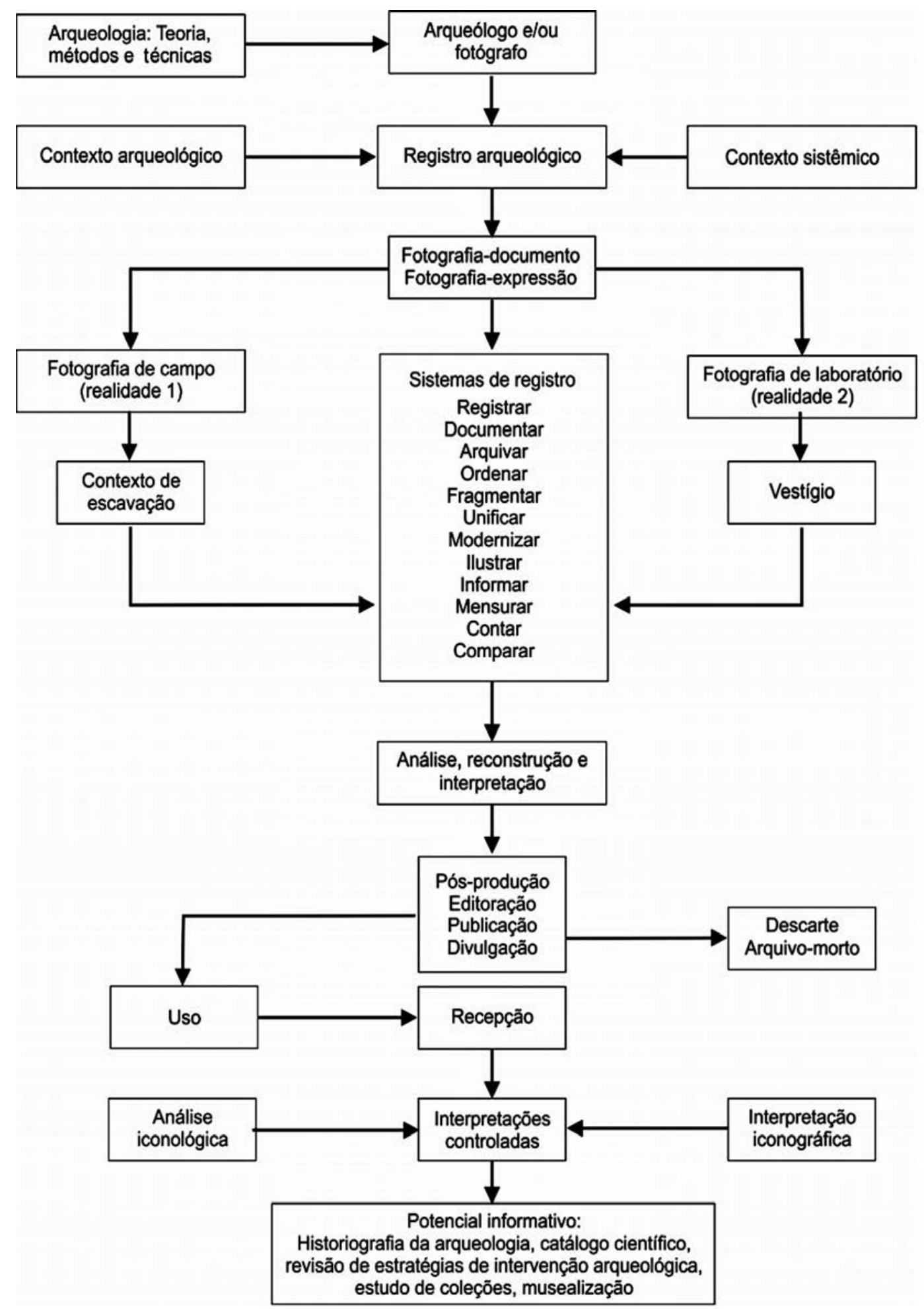

Quadro 3: Fluxograma representando o processo de produção, análise, interpretação e uso dos documentos fotográficos em arqueologia. 
que resulta em grandes acúmulos de dados não utilizados, com efeitos paralisantes - necessariamente perturba muitos aspectos de um sítio. Sendo assim, as fotografias arqueológicas constituem documentos para refinadas comparações possiveis durante a escavação ou, anos depois, em análises de laboratório (os estudos de coleções ).

Os documentos fotográficos em Arqueologia, referentes aos vestígios escavados em determinado sítio podem ser separados em dois grupos e ocorreriam em momentos de espaço e tempo distintos:

a) Fotografias de campo ${ }^{11}$ : são aquelas produzidas pelo arqueólogo e/ou fotógrafo da equipe e estão relacionadas com o registro, a documentação. A notação dos vestígios em seu contexto de escavação, na matriz de sedimento em que estão amalgamados. Ainda referem-se a vegetação que recobre o sítio, sua morfologia, aspectos geológicos, zoológicos, humanos, a própria equipe da escavação e os habitantes da região. Podem ser verticais ou oblíquas, de acordo com o posicionamento e orientação da lente (seu eixo maior) em relação ao plano da superfície a ser fotografada. As fotografias oblíquas relacionam-se às notas e observações pessoais do arqueólogo, enquanto que as verticais prestam-se ao registro objetivo para fins de documentar os achados, servindo à elaboração de croquis de laboratório, fotointerpretação( no caso das aerofotografias e do método da estereoscopia) e fotoidentificação (as sombras saturadas bem como as luzes intensas desgastam o seu caráter objetivo). As fotografias verticais e as oblíquas podem ser obtidas em close-up, representando o objeto nas escalas de $1: 10$ a 1:12. Servem para usos em publicações científicas, jornais, para

(11) São três as categorias de fotografias requeridas para os registros fotográficos de uma escavação: a vertical e a oblíqua, em preto e branco e em cores, objetivando complementar os desenhos dos planos e das secções; as transparências coloridas para aulas e palestras e fotografias, ambas do sítio e dos achados, servirão para ilustrar uma publicação eventual sobre a escavação, segundo Barker (1977, p. 157-160).

(12) Viabilizada por meio de lentes e extensores, esse tipo de fotografia tem sido empregado tanto em campo quanto em laboratório e museus por arqueólogos e conservadores como notas de escavação, em bancos de dados sobre determinados objetos expostos nas vitrines, em catálogos e nas análises e obtenção de fotografias em infravermelho e ultravioleta. serem projetadas na forma de slides em palestras, aulas, elaboração de catálogos para consulta e ilustrações, exposições museológicas, entre outros fins. Essas imagens são, geralmente, usadas para registrar, documentar e ilustrar o que a escavação ofereceu. Os manuais de fotografia arqueológica ensinam como obter registros precisos ou satisfatórios e funcionais, explorando questões técnicas, para servir, inicialmente, como meios e não como fins. Como meios prestam-se como registros objetivos, demonstrando e representando o objeto fotografado. Michael Shanks, então arqueólogo do Department of Archaeology da St David's University College, escreveu um texto primordial e introdutório (SHANKS, 1997) sobre a relação entre Arqueologia e fotografia que difere daqueles dos manuais de fotografia arqueológica que são apresentados neste artigo.

b) Fotografias de laboratório: são aquelas produzidas pelos fotógrafos e/ou arqueólogos em ambiente com iluminação artificial e controlada. $\mathrm{O}$ uso de escalas métricas ou numéricas acentua o caráter de objetividade desse registro. O assunto fotográfico, assim como nas fotografias de campo, torna-se possuidor de referências de proporção métrica linear com o seu referente fotografado, mesmo que a escala não se mantenha constante devido as distorções causadas pelo próprio registro óptico. É forçada a relação de semelhança com o real a fim de tornar a imagem o mais natural possivel, objetiva, isto é, um registro científico. Uma vez em laboratório, as dificuldades de controle de luz e sombra passam a ser outras. Os objetos posicionados e esquadrinhados para o seu novo registro, o fotográfico, funcionam como verdadeiros moduladores da luz artificial incidente, manuseados pelo fotógrafo , bem como pelo arqueólogo, na busca da volumetria, dos contornos, dos sulcos, texturas e cores. A objetividade do registro está na superfície fotograficamente bem representada (próxima do real, mais semelhante possível ao referente). As fotografias obtidas em laboratório podem ser verticais ou oblíquas, macrofotografias ${ }^{13}$

(13) Fotografia de objeto pequeno, em tamanho maior que o natural (1:1 a 50:1). São fotografias em close-up, tiradas dentro de uma faixa de ampliações que abrange desde o tamanho natural até dez vezes essas dimensões. Esse tipo de fotografia foi descrito por Lefkowitz (1979) e no manual da Eastman Kodak Company, de 1977. 
ou microfotografias ${ }^{14}$, sinaléticas, infravermelhas, de Raios -X, digitais, espectroscópicas e estereoscópicas.

Assim, os documentos do "grupo a" referem-se as representações fotográficas cujos referentes estavam sofrendo ações sistemáticas de desmantelamento, desarticulação e desenterramento ocasionados pelas atividades da escavação. Deste modo, relacionam-se diretamente à realidade mesma do contexto arqueológico de acordo com os métodos e técnicas de escavação (abordagem arqueológica) adotados. As fotografias de laboratório (ou estúdio) prestam-se a representação visual do referente fora do seu contexto. É criado um contexto laboratorial, museológico, para o mesmo.

Estes grupos de imagens, ao serem estudados enquanto photoworks, intimamente relacionados a construção do conhecimento arqueológico, constituiriam o próprio objeto de uma Arqueologia através das imagens, Arqueologia Visual. O estudo desses documentos fotográficos através de estratégias de recepção por interpretações controladas (KOSSOY, 1999) constituiria o fazer dessa modalidade de Arqueologia.

O esquema acima acresce à Arqueologia outra modalidade metodológica e técnica, relacionada ao estudo das imagens por ela produzidas, assim como pelos grupos humanos extintos. A cultura material dos grupos estudados passaria ao domínio das demais subdivisões da Arqueologia. A Arqueologia Visual estaria interessada, por exemplo, nas relações entre fotografia e arqueologia , iconografia e arqueologia, necessitando de abordagens multidisciplinares no campo da percepção visual humana e da semiótica. Acervos fotográficos de antigas escavações prestam-se a testar as hipóteses referentes a importância da Arqueologia Visual e sua viabilidade.

Para a decodificação das informações contidas nos documentos fotográficos e em

(14) São obtidas com a câmara acoplada a um microscópio e representam os objetos entre as escalas 25:1 a 1500:1. Equivalente à fotomicrografia, é também entendida como técnica usada para a reprodução de documentos e materiais afins, em filme de formato extremamente reduzido, possibilitando a armazenagem de uma grande quantidade de informações em pouco espaço. seus novos suportes, seria necessária uma inter-relação de documentos (orais, textuais, visuais), como os arquivos fotográficos, os cadernos de campo e demais registros pertencentes aos próprios autores ou as instituições pelas quais publicaram seus artigos.

Entretanto a bibliografia teórica sobre interpretação de fotografias é escassa (desconsiderando as aerofotografias, fotografias de raio-X) . Existem poucas publicações sobre metodologias de análise de fotografias como os trabalhos de Vilches (1987) e Lima (1988), ambos voltados ao estudo das produções fotojornalísticas; de Collier (1995), sobre a produção e uso das fotografias nas pesquisas antropológicas e o potencial de interpretação simbólica das fotografias de arquivos pessoais, discutido por Lacerda (1993). A maior parte da bibliografia refere-se ao estudo de técnicas da fotografia que reconstitui a sua história. São comuns os estudos que utilizam a fotografia como ilustração para reforçar o conteúdo do texto e os estudos que partem da utilização das fotografias como objeto de trabalho, restringindo-se a narrar e a descrever esses documentos visuais.

O processo de identificação dos detalhes icônicos fotográficos, ou a forma sistemática de observar e identificar eventos em uma fotografia, pode estar relacionado aos preceitos de divisão do campo fotográfico sugeridos por I Lima (1988). Essa forma de esquadrinhar a superfície do documento fotográfico com a finalidade de situar e identificar visualmente os detalhes icônicos a serem examinados constitui um esquema de observação útil à Arqueologia Visual. A fotografia pode constituir ainda, uma fonte imediata de informação ou documento para posteriores interpretações e usos. Trabalhos que buscam a relação entre a fotografia documental e a investigação etnológica, procurando confrontar maneiras de apreender o mundo pela arte e pela ciência, unindo segundo Maresca (1998), a criação ao rigor documental representam uma perspectiva da produção do conhecimento antropológico. Entretanto, a arqueologia pode utilizar dessas mesmas prerrogativas para a análise crítica de sua construção científica. A arqueologia busca estabelecer um caráter de cientificidade ao seu objeto de estudo, no qual, 
a fotografia, como documento, aporta parte de um sistema de registro que auxilia nessa busca.

Um segundo recurso, o da interpretação iconológica que possa ocorrer em conjunto com o decorrer da análise iconográfica, diz sobre o contexto histórico do próprio assunto representado. Através de uma iconologia da imagem (interpretação que depende do imaginário do próprio receptor) são buscados significados referentes à primeira realidade fotográfica, ao referente, ao processo criativo e dos procedimentos científicos e as condições ideológicas, culturais, técnicas e estéticas que o recompuseram em objeto fotográfico. A primeira realidade está nos métodos e técnicas empregados para a escavação, seus objetivos e justificativas.

Para uma interpretação iconológica das fotografias convém recuperar os propósitos das escavações, seus motivos geradores e a importância do registro visual dos referentes, dos objetos e suas situações.

Uma vez evidenciados e exumados os vestígios estes podem ser fotografados com diversos recursos tecnológicos e mesmo refotografados - impressos sobre papel ou não. Esses vestígios estão disponíveis à representação fotossensível: in situ podem ser registrados com restrições e dificuldades - a luz solar nem sempre contro- lada, o tempo é restrito as vistas e os detalhes são escolhidos de acordo com o momento da escavação. Representar o contexto arqueológico, da escavação, ou mesmo os vestígios em laboratório, constitui uma atividade difícil, que depende de um "alfabetismo visual" relacionado à arqueologia e seus problemas. As fotografias, juntamente com os instrumentos de escaneamento laser 3D representam sistemas de registro possivelmente mais eficazes em campo. No laboratório, imagens tomográficas 3D e o registro de informações dos espectros ultravioletas e infravermelhos representam novas formas de observar os materiais arqueológicos.

As fotografias obtidas nessas circunstâncias possuíram um caráter científico desejável às escavações sistemáticas. Outra forma de buscar elementos para a interpretação iconológica estaria na pesquisa das recomendações dos manuais de arqueologia de campo e de fotografia arqueológica que foram utilizadas pelos pesquisadores que poderiam estar refletidas nos seus registros fotográficos. Estes, quando são usados para análise do dado de campo, aplicam-se nos estudos indiretos do fenômeno observável do contexto arqueológico. Uma vez terminada a escavação, qualquer recorrência a esses dados, implica na dependência do arqueólogo em relação aos

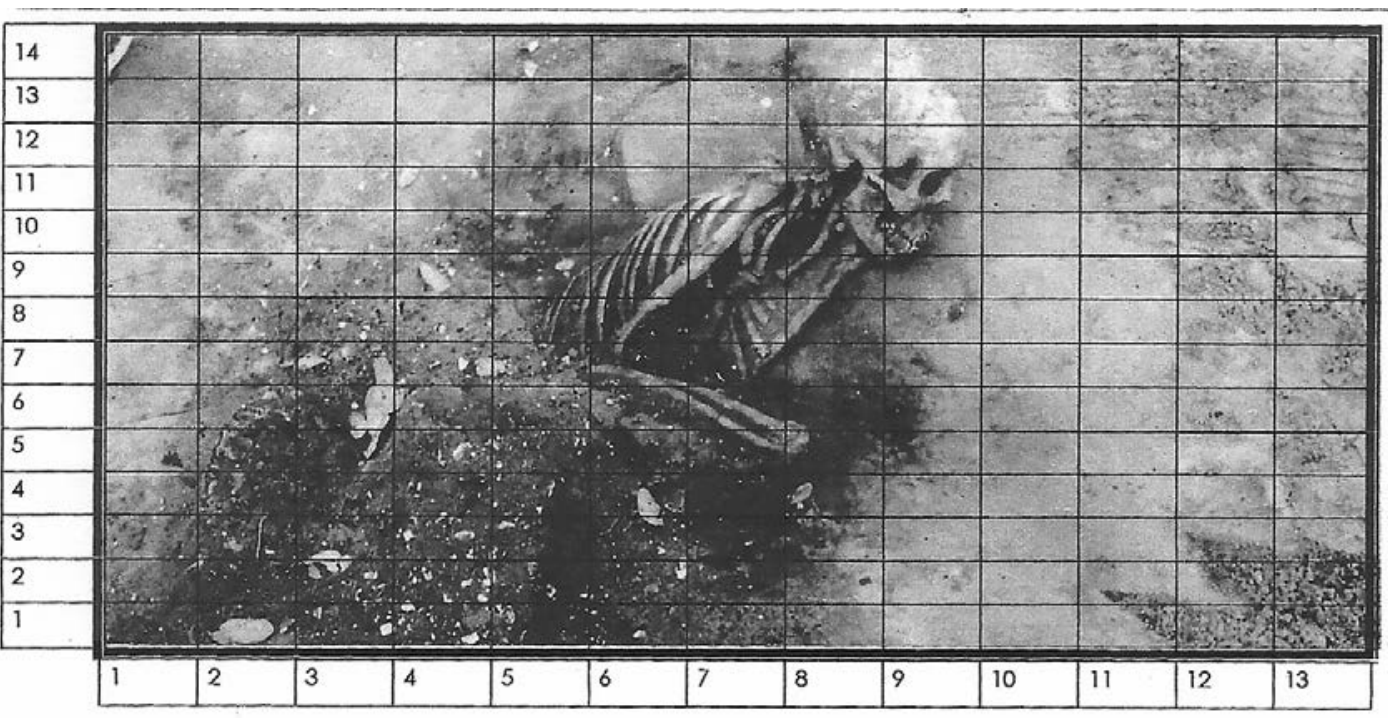

Fig. 4: Régua exploratória de Plecy aplicada sobre fotografia de enterramento do sítio Tenório. Destaque para a possibilidade de situação dos dados do enterramento. 


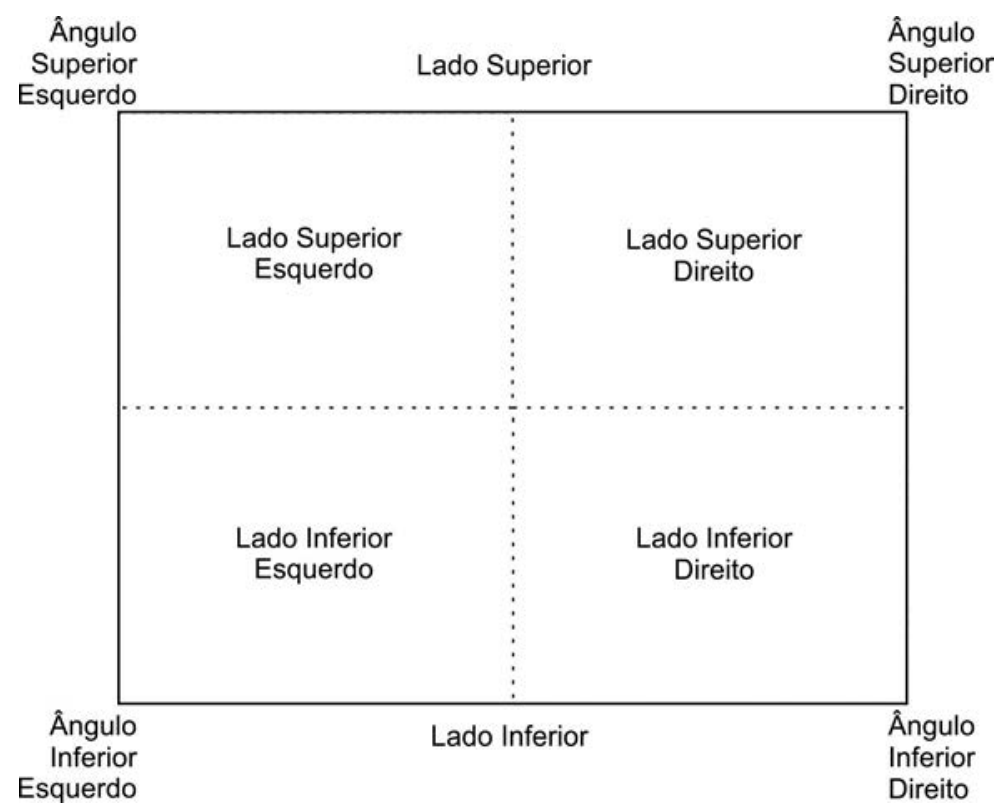

Figura 5: Réguas quadriculadas sugeridas para auxiliar durante o processo de observação da imagem. Sobrepostas à fotografia, ajudam a localizar de maneira sistemática cada elemento construtivo do tema fotografado. Assim, torna-se possível localizar um acompanhamento funerário, entre outros, a partir de sua plotagem na régua.

registros fotográficos. Esses fornecem imagens estáticas da pesquisa de campo, momentos estáticos da experiência visual que restou analisar e interpretar. O exame visual direto das fotografias de campo e laboratório, com o auxílio de réguas auxiliares sugerido por Lima (1988) e Vilches (1987) constitui um dos recursos para o estudo dessa categoria de documentação arqueológica que compõe um photowork. (Cf. Figuras 4 e 5).

\section{Considerações finais: a necessidade de uma Arqueologia Visual}

A relação profunda do registro fotográfico arqueológico com os valores, paradigmas técnicos, físicos e econômicos, teóricos e perceptivos da sociedade industrial contemporânea - segundo Rouillé (2009) - determinou, evidentemente, o desenvolvimento e a involução da fotografia tradicional quando do surgimento da sociedade da informação.

A fotografia-documento que engloba e exprime um acontecimento - e não apenas designa corpos - é a expressão dos acontecimentos, é a fotografia-expressão. Concordamos com Rouillé (2009) quanto ao contexto da transformação do mundo das substâncias, coisas e corpos em um mundo de acontecimentos, de incorporais. A sociedade industrial passa a uma sociedade da informação, a qual:

[...] se estende ao ritmo das redes digitais de comunicação, age profundamente sobre o conjunto das atividades, particularmente sobre as práticas e as imagens fotográficas, segundo processos muitas vezes subterrâneos e silenciosos, mas que colaboram para o esgotamento da fotografia-documento (ROUILLÉ, 2009, p. 187)

Nessa perspectiva, a fotografia arqueológica encontra-se no limiar entre a fotografia-documento e a fotografia-expressão, já explorada pela Antropologia Visual há algumas décadas, considerando as resistências e inovações no uso do dispositivo fotográfico na ciência arqueológica. A fotografia-expressão, ainda com finalidade documental, 
somente propõe vias indiretas de acesso às coisas, fatos e acontecimentos. Assim, construir novas visibilidades implica na revisão dos registros diretos, objetivos e exatos insatisfatórios. No contexto da arqueologia moderna o desafio está em equilibrar o dispositivo fotográfico na tríade documento/expressão/arte na sociedade da informação, pós-industrial. O novo meio de produção e divulgação da fotografia arqueológica é digital, na tela do computador e aparelhos correlatos, com áreas de circulação em rede, implicando na severa desterritorialização da fotografia na medida em que o seu acessar é globalmente instantâneo. Como um documento na produção arqueológica tradicional, as fotografias em suportes multicompostos apresentam um potencial de análise, interpretação e circulação amplo e algumas vezes surpreendente.

Uma Arqueologia Visual na perspectiva similar à da Antropologia Visual torna-se necessária como uma área da arqueologia vinculada ao estudo das imagens fotográficas, fílmicas, em suportes variáveis, conquanto esteja vinculada à historiografia da arqueologia ou a uma história da produção do conhecimento arqueológico. Os conceitos de photowork, sistema de registro, dispositivo fotográfico, são essenciais na configuração desta nova área da arqueologia. Os filmes de exposição, exploração e avaliação (PESSIS, 2000) são recursos da Antropologia Visual que se enquadram perfeitamente no universo da Arqueologia (PESSIS, 1982, 1986), servindo como documentos importantes na análise da construção do conhecimento científico arqueológico.

$\mathrm{Na}$ arqueologia, as fotografias constituem apoio técnico, de modo algum recente nessa ciência, para o registro ou identificação de contextos e artefatos, ou também, para fornecer cenários ilustrativos para exposições museológicas. A fotografia tornou-se uma documentação de momentos específicos, recortes de tempo-espaço do sítio arqueológico em processo de escavação e dos vestígios encontrados. Conforme esse olhar, a:

\section{"[...] arqueologia depende essencial-} mente de uma minuciosa documentação com fotografias, plantas, gráficos, plotações, etc. para o acompanhamento do processo de trabalho, já que a escavação é, simultaneamente, a destruição do sítio arqueológico" (MAGNI e BRUSCHI, 1998, p. 189).

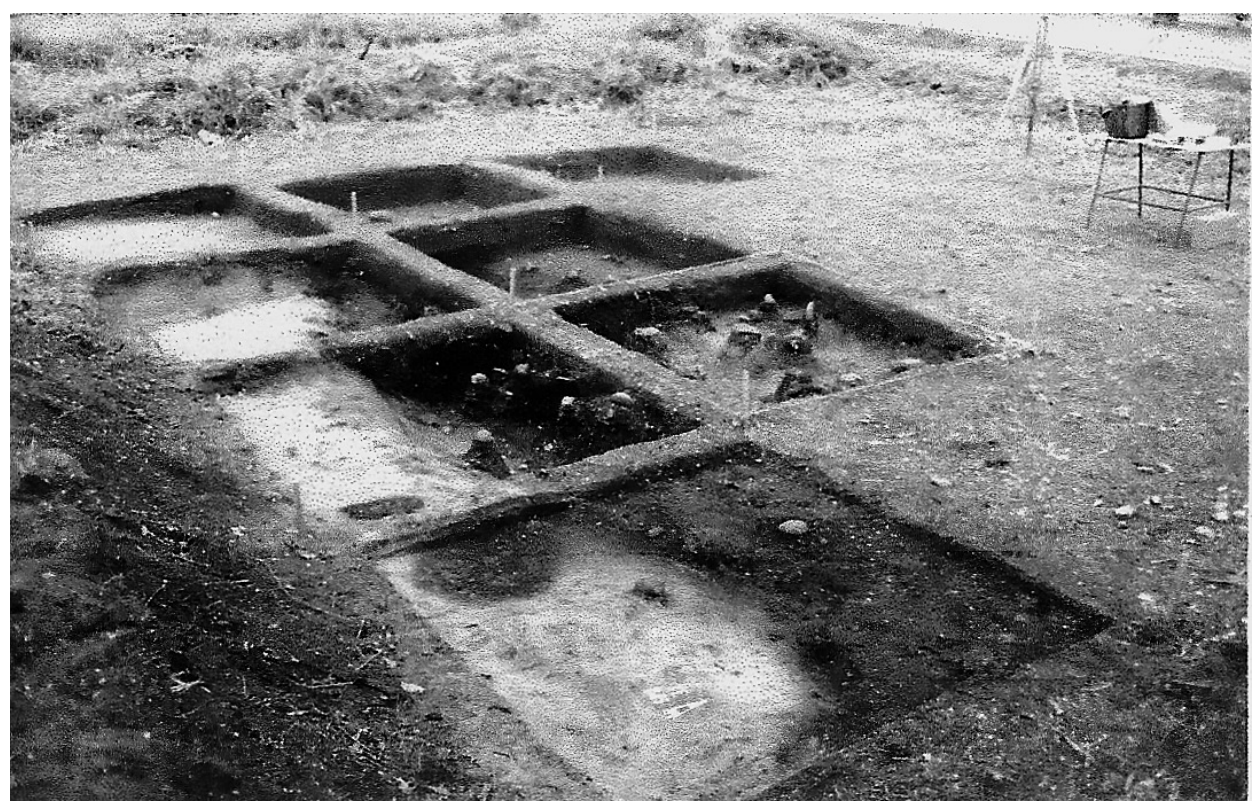

Fig. 6: Fotografia oblíqua geral de parte do setor já limpo e quadriculado (de leste para oeste), com as quadras 45 a 48 e 24 a 27 desbastadas e separadas por divisórias que preservam os perfis laterais das mesmas. Sítio Tenório, Ubatuba, SP, 1970. (Fonte: MAE - USP, 2001) 
Além desse caráter de documentação do objeto de estudo arqueológico, as fotografias retêm, em seu arcabouço de registro, informações que podem ser explorados para a análise da própria construção e evolução da ciência arqueológica. Novos regimes de verdades, uso de imagens e múltiplos conhecimentos técnicos, práticas estéticas e novas relações com o tempo remodelaram o modo de ver o ato fotográfico na arqueologia. $\mathrm{O}$ estudo das imagens produzidas pelos arqueólogos sobre os seus objetos/sujeitos representam um fazer específico que caracteriza uma parcela da área correlata à Antropologia Visual: a Arqueologia Visual (Cf. Figura 6).

SILVA, S.F.S.M.; MÜTZENBERG, D.; CISNEIROS, D. Visual Archaeology: The use of Photography in the production of Archaeological knowledge and to the History of Archaeology. R. Museu Arq. Etn., São Paulo, 22: 137-156, 2012.

\begin{abstract}
This paper presents perspectives for the study of visual data produced by archaeologists during their research. The conscious use of photographic images as variations of a broader archaeological record system, including its systematic production, dissemination and context in the production of scientific knowledge are reviewed in this preliminary study. From the earliest archaeological photographs produced in the nineteenth century, scientific catalogs and manuals, and until recently, with the accelerated development of digital technologies to capture and produce visual images of old photoworks with analytical potential and interpretive perspectives, this work contributes to the understanding about the scientific use of field and laboratory photographs with its relationship with the historiography of archaeology with contribution to Visual Archaeology.
\end{abstract}

Keywords: Visual Archaeology, Archaeological record, Archaeological Methodology, Photography, Historiography of Archaeology

\title{
Referências bibliográficas
}

\section{ARENAS, I. V.}

1986 Arqueología, Ciencia y Sociedad. Boletin de Antropologia Americana, 14: 5-52.

AUMONT, J.

1993 A Imagem. São Paulo: Papirus.

BAHN, P.

2010 Prehistoric rock art: polemics and progress. Cambridge: Cambridge University Press.

BARKER, P.

1977 Techniques of Archaeological Excavation. New York: Universe Books, p. 96-160.

\section{BARTHES, R.}

1984 A Câmara Clara. Rio de Janeiro: Editora Nova Fronteira.
CHÉNE, A.; RÉVEILLAC, G.

1975 La photographie en archéologie. Les Dossiers de l'Archéologie, 3, Nov.-Dec.

COLLIER, J.

1995 Photograph and Visual Antropology. In: HOCKINGS, P (ed.) Principles of the Visual Antropology. 2 ed. New York: Mounton de Gruyter, p. 235-253.

CONLON, V.M.

1971 Camera Techniques in Archaeology. London: University of London.

COOKSON, M B.

1954 Photography for Archaeologists. London: Max Parrish. 
DORRELL, P G

1995 Photography in Archaeology and Conservation. 2 ed. Cambridge: Cambridge Manuals in Archaeology.

DUBOIS, P.

1990 O Ato Fotográfico. São Paulo: Papirus.

EASTMAN KODAK COMPANY

1977 Close-Up Photography $\mathcal{E}$ Photomacrography. p.9-10, 28, 41-48.

EDWARDS, E.

1996 Antropologia e Fotografia. In: Cadernos de Antropologia e Imagem. Rio de Janeiro: UERJ, 2:12.

EHRLICH, R.

1986 Dicionário de Fotografia. Lisboa: Publicações Dom Quixote, p. 71-72, 136.

ERSKINE, C. A.

1965 Photographic Documentation in Archaeological Research: Increasing the Information Content. Science, 148:1089-1090.

FEYLER, G.

1987 Contribution à l'histoire des origines de la photographie archéologique, 1839-1880. Mélanges de l'Ecole Française de Rome. 99 (2).

HARP, E (ED.)

1975 Photography in archaeological research. Albuquerque: University of New Mexico Press.p. 3-15, 345-365.

HEIZER, R. F.; GRAHAM, J. A.

1967 Archaeological Field Photography. In A Guide to Field Methods in Archaeology (Approaches to the Anthropology of the Dead). California/Palo Alto: The National Press, p. 148-157.

HRDLIČKA, A

1910 Contribution to the anthropology of Central and Smith Sound Eskimo. Anthropological papers of the American Museum of Natural History. New York. Vol. 5.

JOUKOWSKY, M.

1986 Field Photography. In: A Complete Manual of Field Archaeology (tools and techniques of field work for archaeologists). New York: Prentice Hall Press, p. 427-442.

KOSSOY, B

1989 Fotografia e História. São Paulo: Ática.

KOSSOY, B.

1999 Realidades e Ficções na Trama Fotográfica. São Paulo: Ateliê Editorial.

\section{KRONE, R.}

1914 Informações Ethnograficas do Valle do Rio Ribeira de Iguape. Commissão Geographica e Geologica do Estado de São
Paulo: Exploração do Rio Ribeira de Iguape. São Paulo.

LACERDA, A. L. DE.

1993 Os Sentidos da Imagem (Fotografias em arquivos pessoais). Acervo, Rio de Janeiro, $6(1-2): 41-54$, jan./ dez.

LACERDA, J. F.; PEIXOTO, J. R.

1876 Contribuições para o estudo anthropologico das raças indígenas do Brasil. Archivos do Museu Nacional do Rio de Janeiro. Rio de Janeiro. Vol 1.

LEFKOWITZ, L.

1979 The Manual of Close-Up Photography. New York: International Center of Photography/Amphoto.

LEMOS, M. DE L.

1992 Registros Visuais na Arqueologia: uma abordagem técnica da linguagem da imagem. Tese de doutorado. São Paulo: Faculdade de Filosofia, Letras e Ciências Humanas USP.

LIMA, I.

1988 A Fotografia é a sua Linguagem. 2 ed. Rio de Janeiro: Ed. Espaço e Tempo.

LÖFGREN, A .

1893 Os Sambaquis de São Paulo. Boletim da Commisão Geographica e Geológica do Estado de São Paulo (contribuição para a archeologia paulista) São Paulo: Typ. a Vapor de Vanorden \& Comp.

LUMBRERAS, L.G.

1982 La Arqueología científico social. 2. ed. Lima: Ediciones Pisa. p.3.

LYTHGOE, A. M.

1965 The Predynastic Cemetery N 7000 Naga-ed-Dêr, Part IV. Berkeley/Los Angeles: University of California Publications. Egyptian Archaeology, 7.

MAGNI, C.T.; BRUSCHI, M.

1998 Em busca do nomadismo da imagem no trânsito entre antropologia e arte. In: SAMAIN, E (org) O Fotográfico, São Paulo: Hucitec/CNPq, p. 185-197.

MARESCA, S.

1998 Olhares cruzados. Ensaio comparativo entre as abordagens fotográfica e etnográfica. In SAMAIN, E . (org.) O Fotográfico. São Paulo: Hucitec, CNPq, p.135-167.

MARTINEZ, M. E LOIZEAU, S.

2006 Estampages, moulages et photographies. historique des premiers essais de relevés scientifiques en art pariétal. In: Lenoir, M. et al. (eds) La Grotte de Pair-Nom-Pair. Bordeaux : Societé Arquéologique de Bordeaux. 
Arqueologia Visual: o Uso das Imagens Fotográficas na Produção do Conhecimento Arqueológico e Historiografia da Arqueologia

R. Museu Arq. Etn., São Paulo, n. 22: 137-156., 2012.

\section{MATTHEWS, S.K.}

1968 Photography in Archaeology and Art. London: John Bake Publications.

MOLYNEAUX, B. L. (ED.)

1997 The Cultural Life of Images: Visual Representation in Archaeology. London: Routledge/ TAG.

MUÑIZ, M. A.; MC GEE, W. J.

1897 Description and discussion of the peruvian crania. Sixteenth annual report of the Bureau of American Ethnology to the Secretary

NEWTON, C.T. of the Smithsonian Institution. Washington.

1862 A History of Discoveries at Halicarnassus, Cnidus and Branchidae. London.

NICHOLS, B.

1981 Ideology and the Image (Social representation in the cinema and other media). Bloomington: Indiana University Press, p.13.

PALLESTRINI, L.; PERASSO, J. A.

1984 Arqueologia: Método y Técnicas en Superfícies Amplias. Paraguay: Biblioteca Paraguaya de Antropologia/Centro de Estúdios Antropológicos de la Universidad Católica N. S.

PESSIS, A-M. de la Asunción.

1982 Métodos de documentação cinematográfica em arqueologia. CLIO. Revista do Curso de Mestrado em História. Recife: UFPE, 5:129-138.

\section{PESSIS, A-M.}

1986 Da antropologia visual à antropologia pré-histórica. CLIO. Revista do Curso de Mestrado em História. Recife: UFPE, 3 (8): 153-161.

PESSIS, A-M.

2000 Registro Visual na pesquisa em Ciências Humanas. Recife: Editora Universitária/ UFPE.
PILLET, $\mathrm{M}$.

1962 Un pionnier de l'Assyriologie: Victor Place. Cahiers de la Societé Asiatique, 16, Paris.

PLACE, $\mathrm{V}$.

1867 Ninive et l'Assyrie. 3 vol. Paris.

ROUILLÉ, A.

2009 A fotografia entre documento e arte contemporânea. São Paulo: Editora Senac São Paulo.

SAMAIN, E.

2005 O Fotográfico. 2. ed. São Paulo: Editora Hucitec/Editora Senac São Paulo.

SANTAELLA, L.; NÖTH, W.

1998 Imagem, cognição, semiótica, mídia. São Paulo: Editora Iluminuras.

SHANKS, M., TILLEY, C.

1992 ReConstructing Archaeology: Theory and Practice. 2.ed. London: Routledge.

SHANKS, M.

1997 Photography and Archaeology. In: MOLYNEAUX, B.L. (ed.) The Cultural Life of Images: Visual Representation in Archaeology. London: Routledge/ TAG, p. 73-107.

STRUEVER, S.

1995 The Role of Film in Archaeology. In HOCKINGS, P (ed.). Principles of Visual Anthropology. New York: Mouton de Gruyter, p. 193-99.

SONTAG, S.

1981 Ensaios sobre Fotografia. Rio de Janeiro: Labor.

VIGNATI, M. A.

1930 Los cráneos trofeo de las sepulturas indigenas de la quebrada de Humahuaca (Provincia de Jujuy). Archivos de Museu Etnográfico da FF y Letras da Universidad de Buenos Aires. Buenos Aires.

VILCHES, L.

1987 Teoría de la Imagem Periodística. Barcelona: Ediciones Paidós. 